\title{
Controlling milk protein interactions to enhance the reconstitution properties of whole milk powders - A minireview
}

\author{
Harjinder SINGH*, Aiqian Ye \\ Riddet Institute, Massey University, Palmerston North, New Zealand \\ Received 26 March 2009 - Revised 17 August 2009 - Accepted 8 September 2009 \\ Published online 16 October 2009
}

\begin{abstract}
Spray-dried milk powders are widely used in recombined milk products and processed foods. The interactions of the specific components in milk, i.e. casein micelles, whey proteins and fat globules, dictate how milk will behave during processing and the functional properties of the powder in different applications. The manufacture of milk powders involves heat treatments, evaporation, homogenisation and spray drying. The major effect of heat treatment is the denaturation of whey proteins and their association with casein micelles. During evaporation, the casein micelle size increases due mainly to the aggregation of some of the micelles and increased association of the whey proteins with the micelles. During whole milk powder manufacture, there are also considerable changes in the size of fat globules and the protein composition of the milk fat globule membrane (MFGM). This modified composition and the consequent reactivity of the MFGM play a major role in determining the functionality of whole milk powders, in particular its reconstitution properties.
\end{abstract}

milk powder / interaction / processing / functionality / solubility

\begin{abstract}
摘要 - 控制乳蛋白质之间的相互作用改善全脂乳粉的还原性。喷雾干燥的乳粉广泛地用于 乳制品和食品加工生产中。乳中特殊的成分, 如酪蛋白胶束, 乳清蛋白和脂肪球之间的相 互作用的结果会在不同的乳制品中表现出不同的特性。乳粉制造过程包括热处理、蒸发、均 质和喷雾干燥。热处理的主要影响是乳清蛋白和乳清一酪蛋白结合蛋白的变性。蒸发过 程, 由于胶束的聚集和乳清蛋白在酪蛋白胶束表面的聚集, 使得酪蛋白胶束增大。在乳粉 的制造过程中，同样也存在脂肪球尺寸的显著增大以及乳脂肪球膜蛋白组成的变化。由于 组成发生变化进而导致脂肪球膜发生的反应对整个乳粉的特性, 特别是还原乳的性质起着 重要的作用。
\end{abstract}

\section{乳粉 / 相互作用 / 加工 / 功能性 / 溶解性}

Résumé - Contrôle des interactions des protéines laitières pour favoriser l'aptitude à la reconstitution des poudres de lait entier. Les poudres de lait séché par atomisation sont largement utilisées dans les produits laitiers recombinés et les aliments transformés. Les interactions des composants spécifiques du lait, comme les micelles de caséines, les protéines sériques et les globules gras, conditionnent le comportement du lait au cours du traitement et les propriétés fonctionnelles de la poudre dans différentes applications. La fabrication de poudres de lait implique traitements thermiques, évaporation, homogénéisation et séchage par atomisation. L'effet principal

*Corresponding author (通讯作者): H.Singh@massey.ac.nz 
$\mathrm{du}$ traitement thermique est la dénaturation des protéines sériques et leur association avec les micelles de caséine. Au cours de l'évaporation, la taille des micelles de caséine augmente, principalement à cause de l'agrégation de certaines micelles et de l'association accrue des protéines sériques avec les micelles. Au cours de la fabrication de poudre de lait entier, il y a également des changements considérables dans la taille des globules gras du lait et dans la composition protéique de leur membrane. Cette composition modifiée et la réactivité conséquente de la membrane des globules gras jouent un rôle important dans la détermination des propriétés fonctionnelles des poudres de lait entier, en particulier leurs propriétés de reconstitution.

\section{poudre de lait / interaction / traitement / propriétés fonctionnelles / solubilité}

\section{INTRODUCTION}

Milk is a complex biological fluid that is highly susceptible to spoilage by the action of naturally occurring enzymes and contaminating microorganisms. A number of processes to preserve milk for long periods and to enhance its utilisation and safety have been developed over the years. Among others, spray drying is the most common processing method for preserving milk [20].

Milk powders are obtained by the partial removal of water from milk and are differentiated on the basis of their fat content into skim milk powder (SMP; also known as non-fat dry milk, NDM) and whole milk powder (WMP). SMPs are commonly classified as low, medium or high heat powders on the basis of their whey protein nitrogen index (WPNI). High protein SMPs with protein content in the range $50-85 \%$ can be produced using membrane technologies. These powders are commonly referred to as milk protein concentrates (MPCs) and may be classified as MPC56, MPC70 and MPC85; the number denotes the approximate protein concentration [2].

Milk powders, intended for various end uses, require consistency of composition, desirable physical attributes and desirable functional properties. The functional properties of milk powders aligned with specific end uses depend on raw milk composition and standardisation, and processing and storage conditions. The composition and the processing conditions (including heat treatment and homogenisation) can be manipulated, to some extent, to achieve desirable functional properties in the powders. Therefore, it is important to understand how various processes, such as heating, concentration, homogenisation and spray drying, used in the manufacture of milk powders influence the native structures and the interactions of milk components, especially milk proteins and fat globules. Relatively little information on the effects of milk component interactions on the structures and functional properties of dried milk products is available.

Among others, the reconstitution properties of milk powders over a wide range of temperatures and $\mathrm{pH}$ values are very important in almost all applications. The process of reconstitution involves mixing water with SMP or WMP. In the recombination process, SMP is dissolved in water, anhydrous milk fat is added and the mixture is then homogenised and pasteurised. Further processing of recombined milk to manufacture specific products follows the standard methods of manufacture of the products from fresh milk. The products that can be made include recombined evaporated milk, recombined UHT milk, recombined sweetened condensed milk, yoghurt, cheese and fermented milk beverages. Milk powders can also be used as functional ingredients in a wide variety of foods, e.g. chocolate, bakery products, beverages and confectionery. In addition, they may be used by consumers directly at home by mixing milk powder and water or by adding milk powder directly to hot coffee or tea [16].

This paper provides an overview of the influence of processing factors on milk 
component interactions during the manufacture of different types of milk powders, with a particular emphasis on WMP. The role of these component interactions in the functionality of milk powders, particularly the reconstitution properties, is discussed in detail. The review largely focuses on the work carried out in our laboratory at Massey University.

\section{PROTEIN INTERACTIONS DURING THE MANUFACTURE OF SMP}

A typical manufacturing process for SMP consists of separation of the fat and pasteurisation of the skim milk, heat treatment of the skim milk for a set time/temperature combination (often referred to as preheating or forewarming), concentration of the milk by a multiple-effect evaporator to remove water, heat treatment of the concentrate and then spray drying of the concentrate.

The proteins in milk vary widely in their susceptibility to denaturation by heat. Caseins are particularly insensitive, whereas the various whey proteins are more or less heat labile. Preheating is an important operation that is used to impart specific functional properties and storage stability to the powder. Preheating temperatures range from $72{ }^{\circ} \mathrm{C}$ for $15 \mathrm{~s}$ to $120^{\circ} \mathrm{C}$ for $2 \mathrm{~min}$, using direct (steam injection) or indirect (plate heat exchanger) heating systems. These heat treatments cause a number of competitive and often interdependent reactions in milk proteins, and many reactions also involve the non-protein constituents of milk. The heat-induced changes in milk have been the subject of many reviews and books $[9,13,21-24,27]$.

The most important heat-induced reactions of milk proteins are denaturation of the whey proteins, interactions of the whey proteins with the casein micelles and aggregation/dissociation of the casein micelles [6, 24]. Preheating milk above $70-75^{\circ} \mathrm{C}$ causes denaturation of the whey proteins, with the order of denaturation being: immunoglobulins $>$ serum albumin $>\beta$-lactoglobulin $A>\beta$-lactoglobulin $\mathrm{B}>\alpha$-lactalbumin [7, 17]. The extent of denaturation of the whey proteins is dependent on both the temperature and the time of heat treatment, but the kinetics of denaturation of the whey proteins are quite complex, with the reaction characteristics showing marked changes above $80-100{ }^{\circ} \mathrm{C}$. The denaturation of $\alpha$-lactalbumin appears to follow a pseudo-first-order reaction, but the order of reaction for $\beta$-lactoglobulin has not been elucidated. Dannenberg and Kessler [7] suggest that a reaction order of 1.5 is best to fit the rate of denaturation, but other workers favour either a first-order [8] or a second-order [11] reaction. Despite these differences, there is general agreement that the denaturation reaction shows a non-linear Arrhenius plot, with a marked change in temperature dependence at about $80-90{ }^{\circ} \mathrm{C}$ for both $\alpha$-lactalbumin and $\beta$-lactoglobulin.

The denaturation of $\beta$-lactoglobulin and the subsequent exposure of sulphydryl groups allow the protein to participate in a number of other reactions that may influence other milk proteins during further processing. These include the well-known interaction of denatured $\beta$-lactoglobulin with $\kappa$-casein in the micelles, which involves the formation of disulphide bonds between $\beta$-lactoglobulin and $\kappa$-casein. Denatured $\beta$-lactoglobulin has also been shown to form complexes with $\alpha_{\mathrm{s} 2}$-casein and $\alpha$-lactalbumin $[19,21]$.

Through their interactions with micellar $\kappa$-casein, some of the denatured whey proteins become associated with the casein micelles. Some remain in the serum where they may form aggregates with other whey proteins or with serum $\kappa$-casein. When the temperature of milk is increased gradually above $70{ }^{\circ} \mathrm{C}$, as in an indirect heating system, most of the $\beta$-lactoglobulin and most 
of the $\alpha$-lactalbumin associate with the micelles, whereas, when milk is heated rapidly, as in a direct heating system (e.g. direct steam injection), about half of the $\beta$-lactoglobulin and half of the $\alpha$-lactalbumin associate with the micelles $[6,17]$. Several other factors also influence the extent of association of denatured whey proteins with the casein micelles; these include the $\mathrm{pH}$ of the milk prior to heating, the levels of soluble calcium and phosphate and the milk solids concentration [21]. Heating at $\mathrm{pH}$ values $<6.7$ results in a greater quantity of denatured whey proteins associating with the casein micelles, whereas, at higher $\mathrm{pH}$ values, whey protein/ $/$-casein complexes dissociate from the micelle surface, apparently as a result of dissociation of $\kappa$-casein [23].

The mechanism of $\beta$-lactoglobulin denaturation and the mechanism of its association with the casein micelles in milk systems have been proposed by Oldfield et al. [17] who suggested that there are at least three possible species of denatured $\beta$-lactoglobulin that could associate with the micelles like (1) unfolded monomeric $\beta$-lactoglobulin, (2) self-aggregated $\beta$-lactoglobulin and (3) $\beta$-lactoglobulin/ $\alpha$-lactalbumin aggregates. The relative rates of association of these species with the casein micelles depend on the temperature and heating rate, which in turn affect the relative rates of unfolding and the formation of the various aggregated species. The $\beta$-lactoglobulin aggregates, which have been shown to be stiff and rod-like, protrude from the surface of the micelles, providing steric effects for further $\beta$-lactoglobulin association. In addition, these aggregates may have their reactive sulphydryl group buried within their interior and therefore unavailable for sulphydryl-disulphide interchange reactions with micellar $\kappa$-casein. In contrast, unfolded monomeric $\beta$-lactoglobulin molecules would be expected to penetrate the $\kappa$-casein hairy layer with greater ease and have a readily accessible sulphydryl group. The formation of unfolded $\beta$-lactoglobulin may be promoted by long heating times at low temperatures or by heating at a slow rate to the required temperature. However, at high temperatures and fast heating rates, all whey proteins begin to unfold in a short period of time, thus presenting more opportunity for unfolded monomeric $\beta$-lactoglobulin to self-aggregate, which consequently is likely to associate less efficiently with the casein micelles. Corredig and Dalgleish [6] suggested that, on heating milk, $\alpha$-lactalbumin and $\beta$-lactoglobulin initially aggregate in the serum phase at a ratio that is dependent on the initial individual whey protein concentrations. On prolonged heating, these complexes subsequently associate with $\kappa$-casein at the casein micelle surface.

As expected, the association of whey proteins with the casein micelles increases the size of the casein particles; the change in size is dependent on the $\mathrm{pH}$ of the milk at heating (at temperatures up to $100{ }^{\circ} \mathrm{C}$ ), which is related to the extent of the association of denatured whey proteins with the micelles. For instance, at $\mathrm{pH} 6.5$, at which about $70 \%$ of the denatured whey proteins are associated with the micelles, the average micelle size increases by about $35 \mathrm{~nm}$. At pH 6.7, at which the level of whey protein association is about $30 \%$, the micelle size increases only by about $5 \mathrm{~nm}$ [1].

There is no further significant denaturation of the whey proteins during the evaporation of skim milk to $45 \%$ total solids and subsequent spray drying [18].

\section{PROTEIN INTERACTIONS DURING THE MANUFACTURE OF WMP}

The manufacturing process for WMP is similar to that for SMP, except that only a portion of the fat is removed during the separation process. The milk is then standardised to achieve the required fat content, preheated and evaporated to $\sim 50 \%$ total 
solids [20]. The concentrate is then homogenised to protect the fat globules from coalescence during spray drying. Instantisation is commonly used in the manufacture of consumer WMPs to improve the reconstitution properties. Instantised powders are manufactured by agglomerating smaller particles with the primary milk powder particles by recirculating the smaller particles ("fines") from the cyclones to some point near the atomiser. The wetting properties of the powder can be improved markedly by spraying phospholipids, e.g. soy lecithin, on the surface of the powder, usually at the start of the external fluidised bed.

In addition to the interactions of whey proteins and casein micelles, described in Section 2 for skim milk systems, the presence of proteins on the fat globule surface (milk fat globule membrane proteins, MFGM) presents another opportunity for protein-protein interactions. MFGM contains over 40 different proteins, ranging in molecular weight from 15 to $240 \mathrm{~kg} \cdot \mathrm{mol}^{-1}$; some major proteins that have been identified are xanthine oxidase $\left(155 \mathrm{~kg} \cdot \mathrm{mol}^{-1}\right)$, butyrophilin $\left(67 \mathrm{~kg} \cdot \mathrm{mol}^{-1}\right)$, PAS 6 $\left(50 \mathrm{~kg} \cdot \mathrm{mol}^{-1}\right)$ and PAS $7\left(49 \mathrm{~kg} \cdot \mathrm{mol}^{-1}\right)$ [12]. The MFGM proteins are known to be highly reactive, as they contain large numbers of disulphide and sulphydryl groups. These proteins denature when whole milk is heated above $60{ }^{\circ} \mathrm{C}$ and the reactive groups are exposed [30].

Using two-dimensional polyacrylamide gel electrophoresis (PAGE), Ye et al. [31] showed that $\beta$-lactoglobulin associates with the MFGM proteins via disulphide bonds on heating whole milk at relatively low temperatures, namely $60-65^{\circ} \mathrm{C}$. This temperature range is lower than that required to denature this protein, implying that this interaction occurs before the free thiol group of $\beta$-lactoglobulin is exposed. It is likely that the free thiol groups for initiating sulphydryl-disulphide interchange reactions between $\beta$-lactoglobulin and MFGM proteins are provided by the MFGM proteins.
The association of $\alpha$-lactalbumin occurs in a similar manner to that exhibited by $\beta$-lactoglobulin, although much lower quantities of $\alpha$-lactalbumin are incorporated into the MFGM. The maximum amount of whey proteins deposited onto the MFGM is usually $\sim 1 \mathrm{mg}$ of whey protein per $1 \mathrm{~g}$ of fat $[5,29]$. The whey proteins in whole milk appear to have more affinity for the MFGM than for the casein micelle surface. Most of the MFGM proteins except PAS 7 $\left(49 \mathrm{~kg} \cdot \mathrm{mol}^{-1}\right)$ are involved in interactions with the whey proteins. PAS 7 shows an unusual behaviour in that it migrates from the MFGM to the serum phase during heating.

In addition to whey proteins, casein micelles also associate with the MFGM via disulphide bonding between $\kappa$-casein and the MFGM proteins. Alternatively, $\beta$-lactoglobulin could associate with the MFGM via sulphydryl-disulphide interchange with the MFGM proteins and could subsequently interact with casein micelles through $\kappa$-casein.

Evaporation of whole milk in a falling film evaporator disrupts the fat globules considerably [32]. A large amount of vapour is removed during evaporation; cavitation caused by vapour evaporation is the most likely reason for the disruption of the fat globules. As the density of the milk increases with an increase in total solids, the cavitation increases, causing further disruption of the fat globules. In addition, air bubbles may also play a part in the disruption of the fat globules during the evaporation of milk. When fat globules simultaneously penetrate the air-plasma interface, the interface compresses because of a decrease in its area, which pushes the globules together and aggregates of fat globules (clumps) are formed [15]. In this situation, the ratio of surface-active material (i.e. casein micelles and whey proteins) to fat at the interface is relatively low; hence, sharing of fat globules at their surface may occur. In the final effect of the evaporation process, 
because much smaller amounts of vapour and air bubbles are produced, the disruption of the fat globules may be caused mainly by turbulent flow as a result of the high density of the concentrated milk. The aggregated fat globules may be disintegrated into individual globules by the forces in the turbulent flow.

During evaporation, the quantities of original MFGM proteins do not change significantly with the decrease in the fat globule size [32]. Proteins from the milk serum are adsorbed onto the newly formed surface, but they do not displace the MFGM proteins. There is little further association of the whey proteins with the MFGM, but the association of casein increases.

When milk concentrate is homogenised, the fat globules are disrupted and reduced in size. As the quantity of original membrane material is not sufficient to cover the newly created surface, there is a marked increase in the adsorption of casein micelles and whey proteins onto the newly created fat surface. Some casein micelles may spread over the surface of the fat globules [28]. The native MFGM proteins remain at the droplet surface. Any heat treatment during processing, including preheating of the raw milk or the concentrated milk, results in association of the whey proteins with the fat globule surface. During preheating, whey proteins associate with the native MFGM proteins and the casein micelles via disulphide bonds; these casein micelle/whey protein complexes are subsequently adsorbed onto the surface of the fat globules during homogenisation, resulting in large increases in the amount of surface whey proteins and the total surface protein load.

Electron microscopic examination of concentrate showed that, after homogenisation, the adsorbed casein micelles, both intact and dissociated, associate with adjacent micelles in the serum to form chains or thread-like structures [28]. These structures may have some role in determining the reconstitution properties of WMPs, as discussed in Section 5.

When whole milk is spray dried, disruption of the fat globules may occur during nozzle/disc atomisation, as the applied pressures are comparable with those used in homogenisers. It is unknown at which step of the drying process the disruption of the fat globules occurs. If it occurs when the concentrate is sprayed into the drying air, i.e. when the concentrated milk comes into contact with the drying air after leaving the atomiser nozzle/disc, evaporation from the surface of the primary particle begins, making the adsorption of protein onto the fat globule surface difficult, particularly at the newly uncovered surface of the fat globules that are located at the surface of the primary particle. In addition, the fat globules located at the surface of the powder particles come into contact with the air-water interface of the drying droplet, which may lead to the fat globules losing membrane and subsequently spreading over the surface of the powder particles [26]. Obviously, the intensity of the heat treatment $\left(\sim 70{ }^{\circ} \mathrm{C}\right)$ during spray drying is not sufficient to cause further association of the whey proteins with the MFGM.

During spray drying, some of the fat globules may coalesce, giving rise to "free" fat on the surface of the powder particles. Often, surface fat or some fat spread over (part of) the surface of the particles of WMP can be observed by a microscopic examination of the reconstituted milk or the powder [3, 4, 14, 33]. However, whether the surface fat is a "free fat" or an "uncovered fat" is still doubtful $[4,25,26]$.

\section{EXAMINATION OF SAMPLES OBTAINED DURING THE COMMERCIAL MANUFACTURE OF WMP}

Commercial samples were obtained from the Fonterra Co-operative Group; 


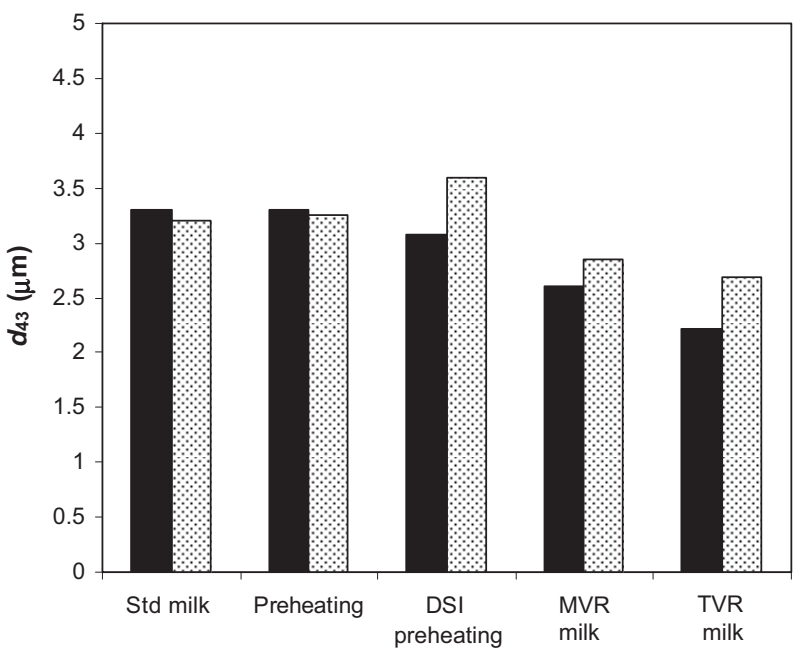

Figure 1. Average size $\left(d_{43}\right)$ of the fat globules in milk samples obtained before and after evaporation. The fat globule size was determined after dispersion in SDS and EDTA buffer (耳) or in water ()) using Matersizer (Malvern Instruments Ltd, Worcestershire, UK). The samples were obtained from the Fonterra Co-operative Group. SDS and EDTA buffer dissociates the aggregated fat globules and protein particles in the samples; thus, the size of fat globules without aggregation was obtained using this determination. The difference between the size, determined in SDS and EDTA buffer and in water, indicates the extent of fat globule aggregation.

Table I. The total protein concentration at the fat globule surface of whole milk before and after evaporation in a whole milk powder plant. The method of determination is described in Ye et al. [32].

\begin{tabular}{lccc}
\hline Sample & $\begin{array}{c}\text { Total } \\
\text { solids }(\%)\end{array}$ & $\begin{array}{c}\text { Total MFGM } \\
\text { protein } \\
\left(\mathrm{mg} \cdot(\mathrm{g} \text { fat })^{-1}\right)\end{array}$ & $\begin{array}{c}\text { Surface protein } \\
\text { coverage of } \\
\text { MFGM }\left(\mathrm{mg} \cdot \mathrm{m}^{-2}\right)\end{array}$ \\
\hline Standardised milk & 10.05 & 7.11 & 1.34 \\
Pasteurised milk & 10.10 & 7.53 & 1.38 \\
Preheated milk & 10.26 & 9.68 & 1.82 \\
DSI-preheated milk & 10.34 & 10.33 & 1.79 \\
MVR concentrate & 34.30 & 23.23 & 3.42 \\
TVR concentrate & 45.32 & 27.22 & 3.89 \\
\hline
\end{tabular}

these included standardised milk (total solids $\sim 10.0 \%$ ), preheated milk $\left(80^{\circ} \mathrm{C}\right)$, direct-steam-injection (DSI)-preheated milk $\left(98{ }^{\circ} \mathrm{C}\right)$ and concentrates after evaporation in the mechanical vapour recompression
(MVR) evaporator (total solids $\sim 34.3 \%$ ) and the thermal vapour recompression (TVR) evaporator (total solids $\sim 45.3 \%$ ). The average size of the fat globules $\left(d_{43}\right)$, determined after dispersion in sodium 


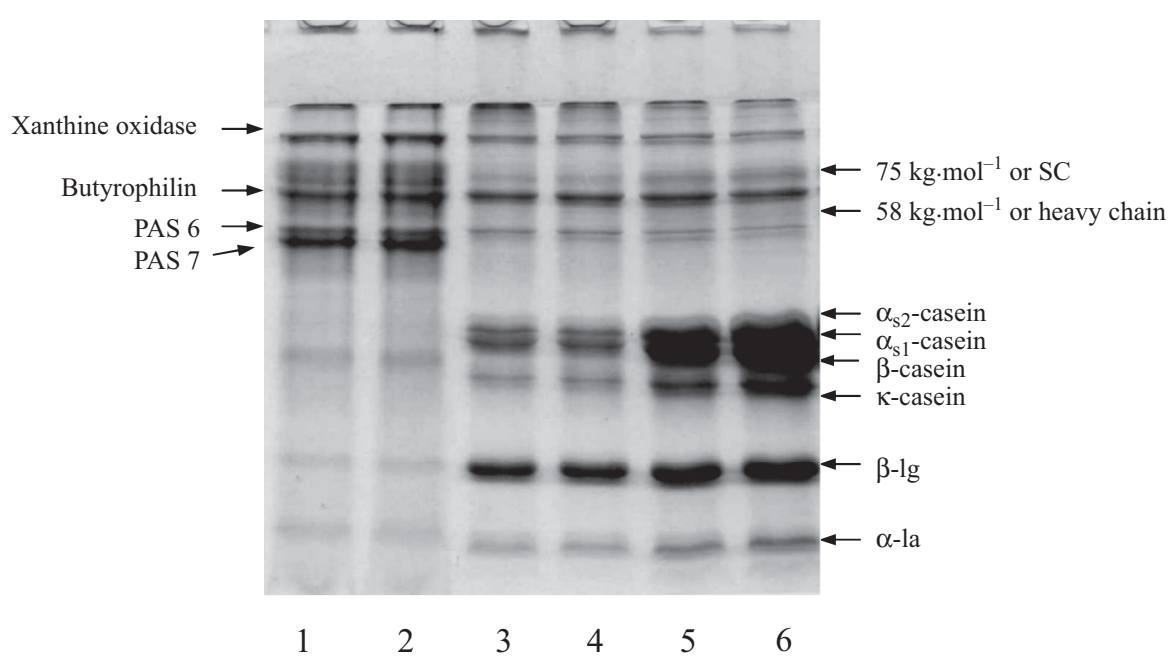

Figure 2. SDS-PAGE patterns (15\% acrylamide gel) under reducing conditions of the MFGM material isolated from milk samples obtained before and after evaporation. The processing of MFGM protein isolation was described in Ye et al. [32]. Lane 1, standardised milk; lane 2, pasteurised milk; lane 3, preheated milk; lane 4, DSI-preheated milk; lane 5, after MVR evaporation; and lane 6, after TVR evaporation.

dodecyl sulphate (SDS) and ethylenediaminetetraacetic acid (EDTA) buffer (containing $2 \%$ SDS and $50 \mathrm{mmol} \cdot \mathrm{L}^{-1}$ EDTA), decreased after DSI preheating $\left(98{ }^{\circ} \mathrm{C}\right)$, MVR evaporation and TVR evaporation (Fig. 1). However, after dispersion in water, the $d_{43}$ values of the preheated and DSI-preheated samples were greater than that of the standardised milk (Fig. 1).

Preheating increased the MFGM proteins slightly (Tab. I), which could be attributed mainly to an apparently higher $\beta$-lactoglobulin content, although some caseins were also observed (Fig. 2). There was a marked increase in the total MFGM protein concentration after evaporation (Tab. I), which involved an increase in the amounts of both caseins and whey proteins ( $\beta$-lactoglobulin and $\alpha$-lactalbumin) (Fig. 2).

No change in the major native MFGM proteins (xanthine oxidase and butyrophilin) was observed after preheating and evaporation. There were decreases in the amounts of PAS 6 and PAS 7 in the preheated samples, and an increase in the intensity of the $\mathrm{SC}$ band (molecular weight $\sim 75 \mathrm{~kg} \cdot \mathrm{mol}^{-1}$ ) after evaporation (Fig. 2).

\section{RECONSTITUTION PROPERTIES OF MILK POWDERS}

The functional properties of milk powders are important when the powders are used for recombining or in the manufacture of various food products. These functional properties, which include emulsification, foaming, water absorption, viscosity, gelation and heat stability, are essentially the manifestation of the physical and chemical properties of the milk.

The most important requirement of many milk powders is reconstitution to form milk that is suitable for further processing. Reconstitutability refers to the ease with which 
a powder can be dissolved in water, i.e. can form a stable colloidal dispersion of fat and casein micelles. Poor solubility is sometimes observed when WMP is dispersed in hot water or hot coffee. The insoluble material can be observed as flecks floating in the solution or as material that settles at the bottom of the container. The reconstitution properties are affected by the processing conditions and the type of equipment, the drier and the system of atomisation, the preheat treatment of the milk and the concentrate, the total solids of the concentrate, the outlet air temperature and the storage time and temperature [10]. This section provides some examples of how processinduced interactions between the proteins themselves and/or the proteins and the fat globules, as described in Sections 2 and 3, influence the reconstitution properties of the WMPs.

Recent work in our laboratory explored the effects of preheat treatment (to alter the MFGM composition) of the milk (prior to evaporation) and homogenisation (to alter the fat globule size) of the concentrate on the reconstitution properties of spray-dried powders. WMPs were manufactured in the pilot plant of the Fonterra Research Centre, Palmerston North. Bulked whole milk was standardised to $3.4 \%$ fat, $3.2 \%$ protein, $4.8 \%$ lactose, $12.0 \%$ total solids and $8.5 \%$ solids-non-fat. The milk was pasteurised at $72{ }^{\circ} \mathrm{C}$ for $15 \mathrm{~s}$ before further processing. Preheating was carried out using a twostage DSI process to bring the milk to the desired temperature $\left(70{ }^{\circ} \mathrm{C}\right.$ for low preheating and $90^{\circ} \mathrm{C}$ for high preheating). The milk was then passed through holding tubes (residence time $20 \mathrm{~s}$ ) to the vacuum vessel, where it was flash cooled to $\sim 70{ }^{\circ} \mathrm{C}$ prior to entry into the first stage of the threeeffect, pilot-scale, falling film evaporator. The milk was evaporated to $\sim 49 \%$ total solids. The concentrated milk samples obtained after evaporation were homogenised in a single-stage homogeniser using a pressure of either 4 or $7 \mathrm{MPa}$ at $50{ }^{\circ} \mathrm{C}$.
The concentrated milk samples after homogenisation were dried in a spray drier with disc atomisation and an integral fluidised bed drier.

The particle size distributions (Fig. 3) showed that the reconstituted powders (in water) made from concentrates that had been homogenised at $7 \mathrm{MPa}$ had more particles in the size range $>10 \mu \mathrm{m}$ than those made from concentrates that had been homogenised at $4 \mathrm{MPa}$ bar. Similar trends were observed for both the low-preheated powders $\left(70{ }^{\circ} \mathrm{C}\right)$ and the high-preheated powders $\left(90^{\circ} \mathrm{C}\right)$.

The $d_{43}$ values of all the powders dispersed in dissociating buffer were fairly similar $(\sim 1.0 \mu \mathrm{m})$ and were lower than those of the powders dispersed in water. The differences in the $d_{43}$ values between the powders dispersed in dissociating buffer and those dispersed in water indicate that the fat globules in these powders were aggregated, to some extent, by protein bridging.

Confocal micrographs of the powders reconstituted in water for $24 \mathrm{~h}$ are shown in Figure 3. The reconstituted powders showed fairly similar fat globule sizes, with some powders showing clusters (arrow) formed by the aggregation of a number of small fat globules. This clustering was evident in the powders made from concentrates that had been homogenised at the higher homogenisation pressure. These fat clusters, which were observed in both the low-preheated powders and the high-preheated powders, were probably related to the larger particles observed in the size determination.

The functional properties of the various powders are shown in Table II. The solubility index, hot sediment and coffee sediment test results showed that the differences in solubility between the individual powders were related to the various processing conditions. The low-preheated powders made from concentrate homogenised at $70 \mathrm{MPa}$ bar had the highest solubility index, hot sediment and coffee sediment. The effect of 

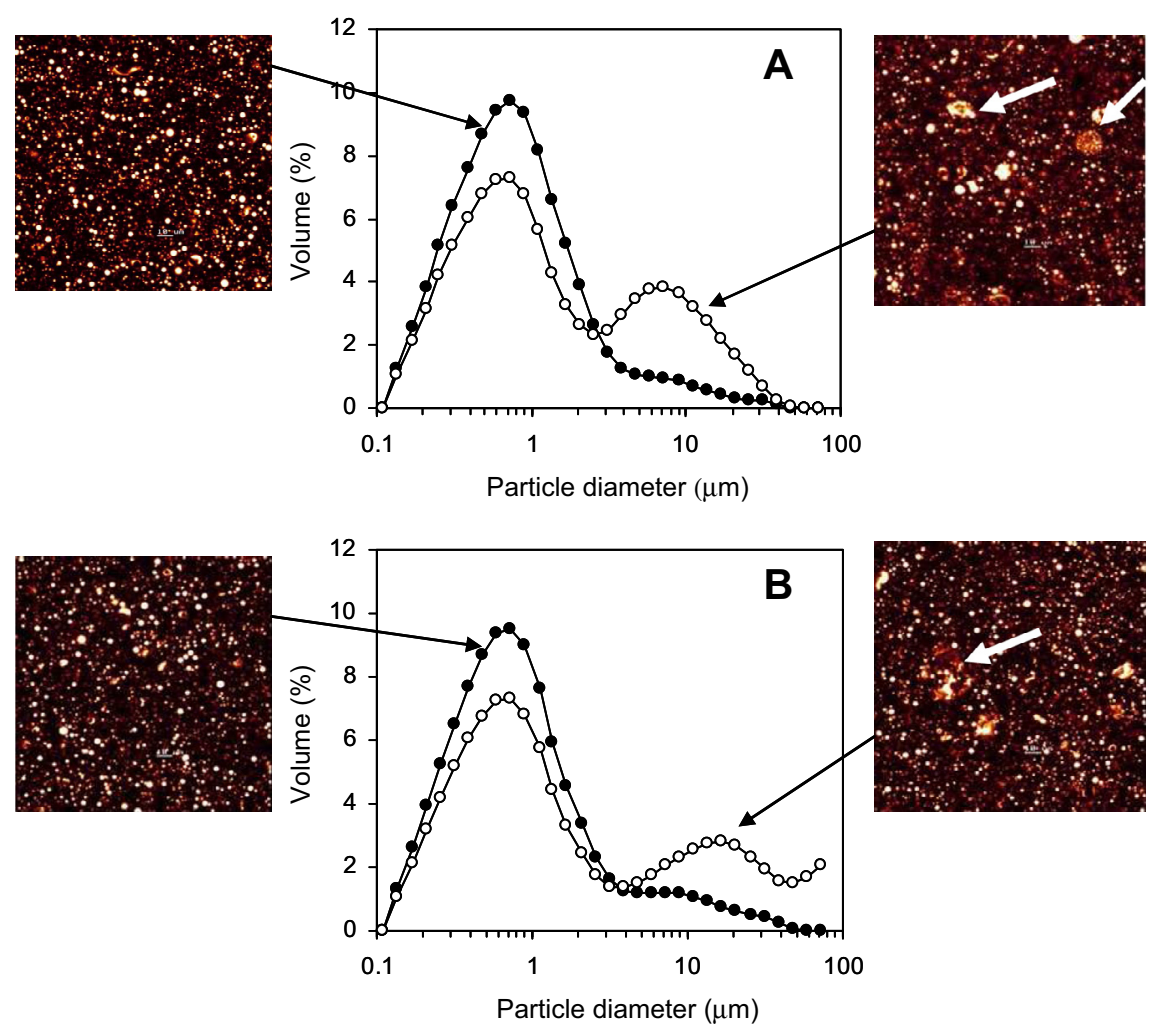

Figure 3. Particle size distributions of the whole milk powders after reconstitution in water determined by Matersizer (Malvern Instruments Ltd, Worcestershire, UK). Low-preheated $\left(70{ }^{\circ} \mathrm{C}\right.$, no holding time) powders (A) and high-preheated $\left(95^{\circ} \mathrm{C}\right.$ for $20 \mathrm{~s}$ ) powders (B); homogenised at $4 \mathrm{MPa}(\bullet)$ and homogenised at $7 \mathrm{MPa}$ bar $(\circ)$. Confocal micrographs of reconstituted milk powder are also presented in figure with arrows. Arrows in the micrographs show aggregated particles in the samples. Confocal microscopy was performed as described by Ye et al. [33].

Table II. Functional properties of WMPs. The methods of determinations are described in McKenna et al. [14].

\begin{tabular}{lcccc}
\hline $\begin{array}{l}\text { Preheat } \\
\text { temperature }\end{array}$ & $\begin{array}{c}\text { Homogenisation } \\
\text { pressure before } \\
\text { drying }(\mathrm{MPa})\end{array}$ & $\begin{array}{c}\text { Solubility index } \\
24{ }^{\circ} \mathrm{C}(\mathrm{mL})\end{array}$ & $\begin{array}{c}\text { Hot sediment } \\
(\mathrm{mL})\end{array}$ & $\begin{array}{c}\text { Coffee sediment } \\
(\mathrm{mL})\end{array}$ \\
\hline $70^{\circ} \mathrm{C}$ & 7 & 1.36 & 1.96 & 2.1 \\
$70^{\circ} \mathrm{C}$ & 4 & 0.25 & 0.4 & 0.65 \\
$90^{\circ} \mathrm{C}, 20 \mathrm{~s}$ & 7 & 0.18 & 1.17 & 0.85 \\
$90^{\circ} \mathrm{C}, 20 \mathrm{~s}$ & 4 & 0.19 & 0.62 & 0.9 \\
\hline
\end{tabular}



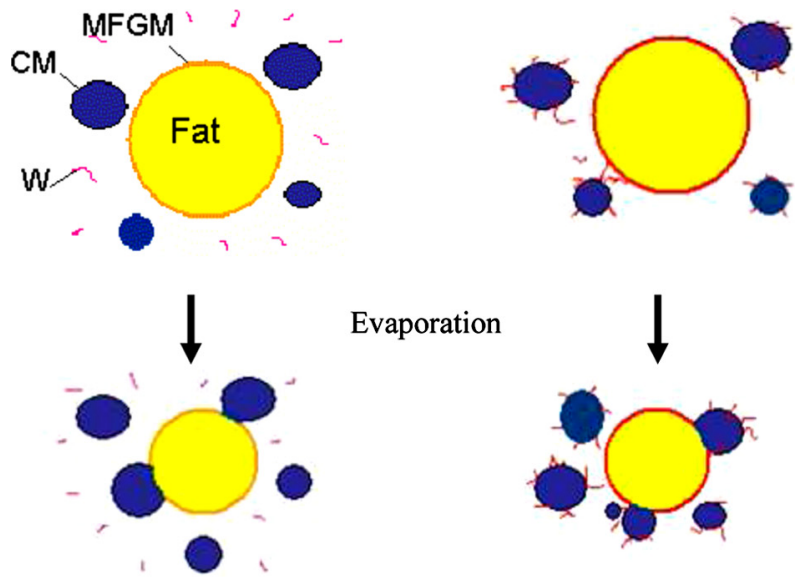

Evaporation

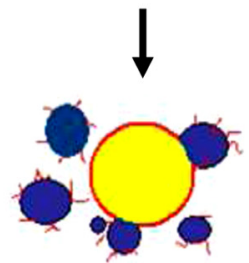

$\downarrow$ Homogenisation \}
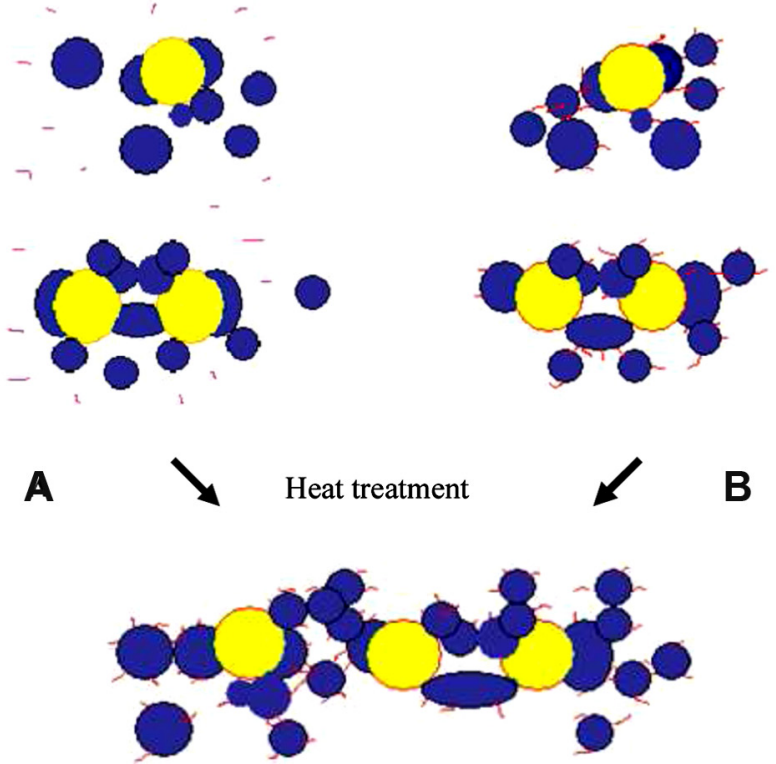

B

Figure 4. Schematic representation of changes in the fat globules and the surface proteins during evaporation, homogenisation and heat treatment. A, non-preheated milk; B, preheated milk; CM, casein micelle; W, whey protein; and MFGM, milk fat globule membrane.

homogenisation pressure on the functionality of the high-preheated powders was less obvious; powders treated at high homogeni- sation pressure had a greater quantity of hot sediment than those treated at low homogenisation pressure. 
From this study, it appears that the clusters of aggregated fat globules that are formed through linkages of interfacial proteins in the powder are related to the solubility properties of the powder. Preheating of the milk appears not to influence the solubility of the powder. A combination of high homogenisation pressure and high heating temperature of the concentrate results in poor solubility. Heat treatment after homogenisation causes the greatest protein interactions at the surface, which leads to poor solubility of the powder.

McKenna et al. [14], using transmission electron microscopy in conjunction with particle size analysis and functional tests, examined a range of commercial WMPs. The most distinguishing feature in these micrographs was the significant quantity of micellar casein material that was associated with the fat globules, and the presence of hair-like structures, which were probably aggregates of denatured whey protein and $\kappa$-casein on the adsorbed casein micelles. The different extent of fat globule clustering in the powders appeared to be related to the solubility of the powders, in which greater fat globule clustering resulted in poor scores for all the solubility-related functional tests, i.e. coffee sediment, hot sediment, cold sediment and slowly dissolving particles. Powder with relatively large numbers of very small fat globules, which had a greater amount of protein associated with the fat globules, had lower values for the solubility test. The adsorption of casein micelles onto the fat globules and the subsequent clustering of the fat globules, possibly caused by the sharing of adsorbed casein micelles between two or more fat globules, were major contributing factors towards the poor functional properties of the powders.

Based on the above discussion, the interactions occurring during the manufacture of WMP could be presented schematically (Fig. 4). Preheat treatments and subsequent evaporation markedly alter the fat globule size and the MFGM composition, resulting in the adsorption of casein micelles and whey proteins onto the fat globules. Concentrate homogenisation further decreases the size of fat globules and increases the amount of protein adsorbed at the fat globule surface. Substantial aggregation or clustering of fat globules involving adsorbed casein micelles and whey proteins may occur upon concentrate heating. In the final WMP, the fat globule surface protein could be composed of three kinds of proteins like (1) the original MFGM proteins, (2) proteins adsorbed from the milk serum because of the disruption of the fat globules and (3) proteins associated with the original MFGM proteins and the adsorbed proteins, as a result of heating.

There is a sufficient evidence to suggest that WMPs with poor reconstitution properties have greater numbers of large aggregated particles that are mixtures of fat globules and proteins than WMPs that are easy to reconstitute. Clearly, the nature of the surface proteins after homogenisation plays a key role in the reconstitution properties of the powder.

A combination of high homogenisation pressure and high temperature treatment of the concentrate before spray drying results in poor reconstitution properties of the powder, particularly when the heating is carried out after homogenisation. This suggests that the poor reconstitution properties of the powder are related to the proteins directly adsorbed at the fat globule surface during homogenisation plus those proteins that are associated with the adsorbed proteins.

\section{REFERENCES}

[1] Anema S.G., Li Y.M., Effect of $\mathrm{pH}$ on the association of denatured whey proteins with casein micelles in heated reconstituted skim milk, J. Agric. Food Chem. 51 (2003) 1640-1646.

[2] Baldwin A., Pearce D., Milk powder, in: Onwulata C. (Ed.), Encapsulated and Powdered 
Foods, Taylor \& Francis, Boca Raton, USA, 2005, pp. 365-386.

[3] Buchheim W., Dejmek P., Milk and dairytype emulsions, in: Larsson K., Friberg S.E. (Eds.), Food Emulsions, 2nd edn., Dekker, New York, USA, 1990, pp. 203-246.

[4] Buma T.J., Free fat and physical structure of spray-dried whole milk, Neth. Milk Dairy J. 25 (1971) 33-72, 88-106, 151-174.

[5] Corredig M., Dalgleish D.G., Effect of different heat treatments on the strong binding interactions between whey proteins and milk fat globules in whole milk, J. Dairy Res. 63 (1996) 441-449.

[6] Corredig M., Dalgleish D.G., The mechanisms of the heat-induced interaction of whey proteins with casein micelles in milk, Int. Dairy J. 9 (1999) 223-236.

[7] Dannenberg F., Kessler H.G., Reaction kinetics of the denaturation of whey proteins in milk, J. Food Sci. 53 (1988) 258-263.

[8] De Wit J.N., Swinkels G.A.M., A differential scanning calorimetric study of the thermal denaturation of bovine $\beta$-lactoglobulin: thermal behaviour at temperatures up to $100{ }^{\circ} \mathrm{C}$, Biochim. Biophys. Acta 624 (1980) $40-48$.

[9] Fox P.F., Heat induced coagulation of milk, in: Fox P.F. (Ed.), Developments in Dairy Chemistry - I. Proteins, Applied Science Publishers, London, UK, 1982, pp. 189-228.

[10] Gaiani C., Scher J., Schuck P., Hardy J., Desobry S., Banon S., Dairy powder rehydration: influence of proteins and some technological effects, J. Dairy Sci. 90 (2007) 570-581.

[11] Hillier R.M., Lyster R.L.J., Whey protein denaturation in heated milk and cheese whey, J. Dairy Res. 46 (1979) 103-111.

[12] Mather I.H., A review and proposed nomenclature for major proteins of the milk-fat globule membrane, J. Dairy Sci. 83 (2000) 203-247.

[13] McCrae C.H., Muir D.D., Heat stability of recombined milk: influence of lecithins on the heat coagulation time-pH profile, J. Dairy Res. 59 (1992) 177-185.

[14] McKenna A.B., Lloyd R.J., Munro P.A., Singh H., Microstructure of whole milk powder and of insolubles detected by powder functional testing, Scanning 21 (1999) 305-315.

[15] Mulder H., Walstra P., The Milk Fat Globule: Emulsion Science as Applied to Milk
Products and Comparable Foods, Commonwealth Agricultural Bureaux, Farnham Royal, UK, 1974, 296 p.

[16] Oldfield D.J., Singh H., Functional properties of milk powders, in: Onwulata C. (Ed.), Encapsulated and Powdered Foods, Taylor \& Francis, Boca Raton, USA, 2005, pp. 365-386.

[17] Oldfield D.J., Singh H., Taylor M.W., Association of $\beta$-lactoglobulin and $\alpha$-lactalbumin with the casein micelles in skim milk heated in an ultra-high temperature plant, Int. Dairy J. 8 (1998) 765-770.

[18] Oldfield D.J., Singh H., Taylor M.W., Effect of preheating and other process parameters on whey protein reactions during skim milk powder manufacture, Int. Dairy J. 15 (2005) 501-511.

[19] Patel H.A., Singh H., Anema S.G., Effects of heat and high hydrostatic pressure treatments on disulfide bonding interchanges among the proteins in skim milk, J. Agric. Food Chem. 54 (2006) 3409-3420.

[20] Pisecky J., Technology of skimmed milk drying, J. Soc. Dairy Technol. 34 (1981) 57-62.

[21] Singh H., Heat-induced changes in caseins including interactions with whey proteins, in: Fox P.F. (Ed.), Heat-induced Changes in Milk, International Dairy Federation, Brussels, Belgium, 1995, pp. 86-99.

[22] Singh H., Creamer L.K., Heat stability of milk, in: Fox P.F. (Ed.), Advanced Dairy Chemistry - I. Proteins, Elsevier, London, UK, 1992, pp. 621-656.

[23] Singh H., Fox P.F., Heat stability of milk: $\mathrm{pH}$-dependent dissociation of micellar $\kappa$-casein on heating milk at ultrahigh temperatures, J. Dairy Res. 52 (1985) 529-538.

[24] Singh H., Newstead D.F., Aspects of proteins in milk powder manufacture, in: Fox P.F. (Ed.), Advanced Dairy Chemistry - I. Proteins, Elsevier, London, UK, 1992, pp. 735-765.

[25] Vignolles M.L., Jeantet R., Lopez C., Schuck P., Free fat, surface fat and dairy powders: interactions between process and product. A review, Lait 87 (2007) 187-236.

[26] Walstra P., Physical chemistry of milk fat globules, in: Fox P.F. (Ed.), Advanced Dairy Chemistry, Volume 2: Lipids, Chapman \& Hall, London, UK, 1995, pp. 131-171.

[27] Williams R.P.W., D'Ath L., Zisu B., Role of protein aggregation in heat-induced stability 
during milk powder manufacture, Dairy Sci. Technol. 88 (2008) 121-147.

[28] Ye A., Singh H., Anema S., Changes in the surface protein of the fat globules during homogenization and heat treatment of concentrated milk, J. Dairy Res. 75 (2008) 347-353.

[29] Ye A., Singh H., Oldfield D., Anema S., Kinetics of heat-induced association of $\beta$-lactoglobulin and $\alpha$-lactalbumin with milk fat globule membrane in whole milk, Int. Dairy J. 14 (2004) 389-398.

[30] Ye A., Singh H., Taylor M.W., Anema S., Characterization of protein components of natural and heat-treated milk fat globule membranes, Int. Dairy J. 12 (2002) 393-402.
[31] Ye A., Singh H., Taylor M.W., Anema S., Interactions of whey proteins with milk fat globule membrane proteins during heat treatment of whole milk, Lait 84 (2004) 269-283.

[32] Ye A., Singh H., Taylor M.W., Anema S., Interactions of fat globule surface proteins during concentration of whole milk in a pilot-scale multiple-effect evaporator, J. Dairy Res. 71 (2004) 471-479.

[33] Ye A., Singh H., Taylor M.W., Anema S., Effect of spray drying on the milk fat globule and membrane proteins during the manufacture of whole milk powders, Int. Dairy J. 17 (2006) 374-382. 